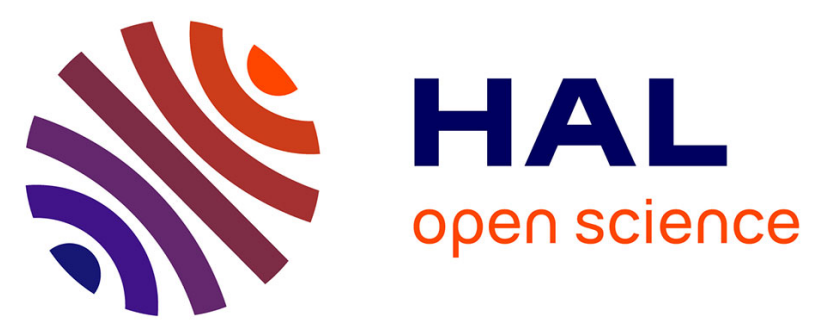

\title{
Origin and diagenesis of lignin and carbohydrates in mangrove sediments of Guadeloupe (French West Indies): Evidence for a two-step evolution of organic deposits
}

Elisabeth Lallier-Vergès, Cyril Marchand, Jean-Robert Disnar, Nathalie Lottier

\section{To cite this version:}

Elisabeth Lallier-Vergès, Cyril Marchand, Jean-Robert Disnar, Nathalie Lottier. Origin and diagenesis of lignin and carbohydrates in mangrove sediments of Guadeloupe (French West Indies): Evidence for a two-step evolution of organic deposits. Chemical Geology, 2008, 255, pp.388-398. 10.1016/j.chemgeo.2008.07.009 . insu-00318482

\section{HAL Id: insu-00318482 \\ https://hal-insu.archives-ouvertes.fr/insu-00318482}

Submitted on 4 Sep 2008

HAL is a multi-disciplinary open access archive for the deposit and dissemination of scientific research documents, whether they are published or not. The documents may come from teaching and research institutions in France or abroad, or from public or private research centers.
L'archive ouverte pluridisciplinaire HAL, est destinée au dépôt et à la diffusion de documents scientifiques de niveau recherche, publiés ou non, émanant des établissements d'enseignement et de recherche français ou étrangers, des laboratoires publics ou privés. 


\title{
Origin and diagenesis of lignin and carbohydrates in mangrove sediments of Guadeloupe (French West Indies): Evidence for a two-step evolution of organic deposits
}

\author{
E. Lallier-Vergès ${ }^{a}$, C. Marchand ${ }^{b}$, J.-R. Disnar ${ }^{a}$ and N. Lottier ${ }^{a}$ \\ ${ }^{a}$ Institut des Sciences de la Terre d'Orléans, CNRS-Université d'Orléans, 1A rue de la \\ Férollerie, 45071 France ${ }^{\mathrm{b}}$ Institut de Recherche pour le Développement (IRD), UR 103 \\ CAMELIA, Nouméa, BPA5, 98848, New-Caledonia, France
}

\begin{abstract}
The mangroves of Grande Terre Island (Guadeloupe, French West Indies) are known to store large amounts of organic carbon, and organic-rich sediments have been described to several meters depth. The purpose of the present work was to precisely determine the molecular composition (carbohydrates and lignin-derived phenols) of these organic deposits in relationship with environmental conditions. It was found that within the upper meter of the cores, geochemical data displayed the classical degradation pattern of organic matter (OM) deriving from higher plants. On the one hand, carbohydrates from mangrove tissues underwent fast decomposition, other compounds being simultaneously synthesized by bacteria. On the other hand, lignin phenols were lost rather slowly, i.e. at a similar or lower rate than TOC, their distribution with depth evidencing various lignin decomposition pathways depending on redox conditions. The position of the swamp with respect to salt and fresh water tables strongly influenced these conditions. At depth, results revealed an organicrich layer, which was characterized by surprisingly well-preserved OM with regard to sugar and phenol compositions. We speculate that the preservation of these compounds might be explained by a rapid and permanent flooding of the mangrove stands that may have occurred more than a thousand years ago. We suggest that the geodynamic context, i.e. the recurrent seismic activity recorded in Guadeloupe, may have induced such a flooding, resulting in the preservation of this OM.
\end{abstract}

Keywords: Mangrove; Carbohydrates; Lignin-derived phenols; Early diagenesis; Guadeloupe

\section{Introduction}

Mangrove forests, which develop in the intertidal zone of tropical and subtropical coastlines, are among the most productive terrestrial ecosystems, and can be characterized by a strong organic accumulation in their substrate ([Chen and Twilley, 1999], [Bouillon et al., 2003], [Chmura et al., 2003] and [Bouillon et al., 2008]). Additionally, the decay processes of organic matter $(\mathrm{OM})$ in mangrove sediments are highly variable, due to the mixing of marine and fresh water, and to the activity of root systems and macrofauna ([Alongi et al., 2000], [Marchand et al., 2004] and [Kristensen et al., 2008]). Consequently, mangroves constitute a natural laboratory to study present processes of preservation/decomposition of higher plant remains in waterlogged sediments.

The mangrove of "Le Grand Cul-de-Sac Marin", located on Grande Terre Island (Guadeloupe, French West Indies), is characterized by a clear zonation pattern of mangrove species from saline to fresh water. Rhizophora mangle develop on saline sediments, with 
salinity values ranging from 30 to 40, Acrostichum aureum and Laguncularia racemosa on a brackish substrate, with salinity values ranging from 10 to 20, and Pterocarpus officinalis and Cladium marescus on a nearly fresh water soil, with salinity values lower than 5 (LallierVergès et al., 1998). This mangrove swamp system has been aggrading at the same place for several centuries (Feller et al., 1990). In a previous study (Lallier-Vergès et al., 1998), we showed that the sedimentary record reached about 1400 years BP at $180 \mathrm{~cm}$ depth beneath the more marine $R$. mangle stand. Beneath the more continental $P$. officinalis forest, the record reached about 1400 years BP at only $65 \mathrm{~cm}$ and $2700 \mathrm{BP}$ at $185 \mathrm{~cm}$ depth. Accordingly, this mangrove is characterized by a very high sedimentary organic content, with TOC values ranging from 17 to $48 \%$ on $2 \mathrm{~m}$ deep profiles, which is among the highest TOC values ever measured in mangrove ecosystems. Using $\mathrm{C} / \mathrm{N}$ ratios, Rock-Eval pyrolysis data, $\delta^{13} \mathrm{C}$ values and microscopic observations and counts, Lallier-Vergès et al. (1998) demonstrated that there was a strong link between pore water chemistry (i.e. salinity and redox values) and organic matter contents, both in terms of quantity and quality. Finally at depth, an unexpected OMrich layer, characterized by high $\mathrm{C} / \mathrm{N}$ ratios and low $\delta^{13} \mathrm{C}$ values, was observed beneath most of the mangrove stands.

Carbohydrates and lignin-derived phenols, which are among the main organic components of vascular plants, are powerful indicators to trace higher plant remains and thus mangrovederived OM in coastal environments ([Benner et al., 1990], [Opsahl and Benner, 1995] and [Dittmar et al., 2001]). Carbohydrates, which can be divided into storage and structural components, can represent up to $65 \%$ of organic carbon in mangrove wood (Opsahl and Benner, 1999). Additionally, clear distinctions can be made between the carbohydrate signatures of mangrove wood and leaves ([Lallier-Vergès et al., 1999] and [Marchand et al., 2005]). However, these signatures tend to disappear rapidly in the early stages of diagenesis with the degradation of the considered constituents (Moers et al., 1990). Compared to sugars, lignin-derived phenols are more resistant to diagenesis (Sarkanen and Ludwig, 1971). Lignin only occurs in higher plants. Its monomeric composition varies between gymnosperms and angiosperms, and between woody and leaf tissues (Hedges and Mann, 1979a). Specific ratios between lignin monomers can also be used as indicators of diagenetic alteration ([Hedges and Ertel, 1982], [Ertel and Hedges, 1984], [Hedges et al., 1988], [Bianchi et al., 1999] and [Miltner et al., 2005]).

Since the studied area exhibits a clear zonation pattern of mangrove species, the first aim of the present study was to compare the distribution of carbohydrates and of lignin-derived phenols in both mangrove plants and sediments in order to evaluate their potential use as mangrove source tracers. The second intent was to assess the fate of these constituents during early diagenesis depending on the respective position of the various stands regarding saline and fresh water input. Finally, the characterization of the $\mathrm{OM}$ at the molecular level was undertaken to obtain information on the nature and the origin of the specific OM-rich layer observed at depth.

\section{Materials and methods}

\subsection{Study site and field sampling}

Guadeloupe (French West Indies) is situated between $15^{\circ} 57^{\prime} \mathrm{N}$ and $16^{\circ} 31^{\prime} \mathrm{N}$, and between $61^{\circ} 10^{\prime} \mathrm{W}$ and $61^{\circ} 48^{\prime} \mathrm{W}$ (Fig. 1). This island is characterized by a tropical climate with a mean annual rainfall ranging from 1500 to $1800 \mathrm{~mm}_{\text {year }}^{-1}$ occurring in a bimodal pattern (with a major rainfall period extending from July to November). Sampling was carried out in 
June, at the end of the dry season. $2 \mathrm{~m}$ long cores were collected at low tide with an Eijkelkamp ${ }^{\circledR}$ gouge auger beneath the 5 mangrove species ( $R$. mangle, L. racemosa, $A$. aureum, $C$. marescus, and $P$. officinalis), along a $2000 \mathrm{~m}$ long transect (Fig. 1d). After being collected, cores were wrapped in plastic film and aluminium foil in order to limit gaseous exchanges. Wood and leaves of the various plant species were also picked up from several trees surrounding the coring sites. The elevation of the soil was not measured but we observed that Cladium and Pterocarpus forests were not daily inundated by tides and were thus at a higher topographic level than the other mangroves. For the bulk analyses the results of which were presented in Lallier-Vergès et al. (1998), cores were sampled at $1 \mathrm{~cm}$ intervals in the upper $10 \mathrm{~cm}$, then as $2 \mathrm{~cm}$-thick samples every $10 \mathrm{~cm}$ down to $60 \mathrm{~cm}$ and every $20 \mathrm{~cm}$ below $60 \mathrm{~cm}$. For the molecular analyses presented herein, 6 samples per core were selected as a function of the bulk results.

\subsection{Lignin-derived phenol analysis}

Air-dried samples were hydrolysed with $2 \mathrm{~N} \mathrm{NaOH}$ for $4 \mathrm{~h}$ at $170{ }^{\circ} \mathrm{C}$ in presence of $\mathrm{CuO}$. After addition of 2, 4, 5 trimethoxy benzoic as an internal standard, $\mathrm{NaOH}$ was neutralised with $6 \mathrm{~N} \mathrm{HCl}$. The phenols were then extracted with di-ethyl ether and were further separated and quantified by capillary zone electrophoresis (thanks to the analysis of an external standard mixture of the studied phenolic compounds; Maman et al., 1996). " $\mathrm{X}_{\text {lignin }}$ " represents the total yield of 8 simple phenols: vanillyl and syringyl acids, aldehydes and ketones, plus two cinnamic compounds ( $p$-coumaric and ferulic acids). This parameter does not take into account the $p$-hydroxy-benzylic moieties that can be derived from non vascular plant material (Goñi and Hedges, 1995). "X $\mathrm{X}_{\text {lignin }}$ " is expressed in mmol of lignin carbon per $100 \mathrm{mmol}$ of total organic carbon (mmol phenolic $\mathrm{C} / 100 \mathrm{mmol}$ TOC). " $\Sigma 11$ " is the sum of $\mathrm{X}_{\text {lignin }}$ and $p$ hydroxyl phenols (mmol phenolic $\mathrm{C} / 100 \mathrm{mmol}$ total OC). The $\mathrm{C} / \mathrm{V}$ ratio is defined as the ratio of the sum of the cinnamic acids over the sum of the vanillic moieties (aldehyde + ketone + acid); the $\mathrm{S} / \mathrm{V}$ ratio is defined as the ratio of the sum of the syringic phenols over the sum of the vanillic phenols. $(\mathrm{Ad} / \mathrm{Al})_{\mathrm{v}}$ is the molar ratio of vanillic acid to vanillin (aldehyde). $(\mathrm{Ad} / \mathrm{Al})_{\mathrm{s}}$ is the molar ratio of syringic acid over syringaldehyde.

\subsection{Carbohydrate analyses}

Neutral sugar analyses were carried out in 2 independent steps according to a modified Cowie and Hedges procedure (1984). Both these steps mostly consist in a hydrolysis with dilute acid solution $\left(2.4 \mathrm{~N} \mathrm{H}_{2} \mathrm{SO}_{4}\right)$, but with and without previous soaking of the analysed sample with concentrated acid $\left(24 \mathrm{~N} \mathrm{H}_{2} \mathrm{SO}_{4}\right)$. The first step with previous soaking yields the Total Sugars (i.e. cellulosic + hemicellulosic), whereas the second step which only consists in a simple hydrolysis with dilute acid only releases the most labile hemicellulosic monomers. Finally, the amounts of cellulosic monomers were calculated by subtracting the results of the second step to those of the first step.

Concerning the first step, in a Pyrex tube, $1 \mathrm{ml}$ of $24 \mathrm{~N} \mathrm{H}_{2} \mathrm{SO}_{4}$ was added to $30 \mathrm{mg}$ of plant material or $100 \mathrm{mg}$ of sediments, previously dried. After $16 \mathrm{~h}$ at room temperature, the solutions were diluted to $2.4 \mathrm{~N} \mathrm{H}_{2} \mathrm{SO}_{4}$. The tubes were tightly closed under vacuum and heated at $100{ }^{\circ} \mathrm{C}$ for $5 \mathrm{~h}$. After cooling, 6-deoxy-d-glucose $(400 \mu \mathrm{g})$ was then added as an internal standard and the samples were subsequently neutralised with $\mathrm{CaCO}_{3}$. The precipitate was removed by centrifugation at $3000 \mathrm{rpm}$ for $20 \mathrm{~min}$. After evaporation of the supernatant to dryness, the extracted sugars were dissolved in methanol at $50{ }^{\circ} \mathrm{C}$. After evaporation of the solvent, the residue was stored in a desiccator. 
The sample extracts were dissolved in pyridine, derivatised with trimethylsilyl (Sylon BFT Supelco), and immediately analysed using a Perkin Elmer gas chromatograph fitted with a $25 \mathrm{~m}$ long, $0.25 \mathrm{~mm}$ i.d. DB-1 capillary column (CPSil5CB, $0.25 \mu \mathrm{m}$ film thickness), and an FID detector. The temperature program began at $60{ }^{\circ} \mathrm{C}$, then the oven temperature was raised at a rate of $30^{\circ} \mathrm{C} \mathrm{min}{ }^{-1}$ up to $120^{\circ} \mathrm{C}$ where it was maintained for $1 \mathrm{~min}$, then raised again to $240{ }^{\circ} \mathrm{C}$ at $3{ }^{\circ} \mathrm{C} \mathrm{min}^{-1}$ and finally at a rate of $20^{\circ} \mathrm{C} \mathrm{min}{ }^{-1}$ up to $310^{\circ} \mathrm{C}$ were it was kept for $10 \mathrm{~min}$. The injector split was off at the start time and turned on after $2 \mathrm{~min}$. The injector was maintained at $240{ }^{\circ} \mathrm{C}$, the detector at $300{ }^{\circ} \mathrm{C}$. Replicate analyses gave an analytical precision lower than 5\% for neutral sugar analyses of plant material and between $10 \%$ and $15 \%$ for sediments. Eight monosaccharides were identified in mangrove plants and in sediments: ribose, arabinose, xylose, rhamnose, fucose, glucose, mannose and galactose. The total neutral sugar concentrations are expressed in mmol of carbon of neutral monosaccharides per $100 \mathrm{mmol}$ of total organic carbon (mmol TCOH-C/100 mmol OC).

\section{Results}

\subsection{Molecular composition of mangrove plant species}

The carbohydrate and lignin-derived phenol compositions of wood and leaves of the five mangrove species ( $R$. mangle, L. racemosa, A. aureum, C. marescus, and P. officinalis) developing along the studied transect are presented in Table 1 . TOC values of all plant tissues ranged between 32 and $39 \%$.

Some distinctions in the phenol distribution can be made between the various species. The compositions of Rhizophora and Laguncularia were quite similar with a balanced proportion of the 4 phenol units (i.e. syringic, vanillic, cinnamic and $p$-hydroxy-benzylic) in leaves, and a dominance of syringic and vanillic units in wood. Cladium, which was the richest in lignin oxidation products $(9.85 \mathrm{mmol}$ phenolic $\mathrm{C} / 100 \mathrm{mmol}$ TOC), had a composition close to that of Rhizophora and Laguncularia woody tissues. The fern Acrostichum was characterized by a dominance of vanillic units, namely $80 \%$ of total phenols in leaves and up to $97 \%$ in stems. Finally, Pterocarpus was characterized by a low content in cinnamic and $p$-hydroxy-benzylic units, representing together less than $15 \%$ of total phenols even in the leaves. Additionally, clear distinctions in the phenol composition can be made between wood and leaves. Woods were richer in lignin oxidation product than leaves. $\mathrm{X}_{\text {lignin }}$ (see experimental) values ranged from 0.9 to 4.9 and from 4.1 to $8.8 \mathrm{mmol}$ phenolic $\mathrm{C} / 100 \mathrm{mmol} \mathrm{TOC}$ in leaves and woody material, respectively. Mangrove woods were relatively poor in cinnamic units, namely between 1 and $5 \%$ of total phenols. As a consequence, woody tissues were characterized by very low $\mathrm{C} / \mathrm{V}$ ratio values, close to 0.1 (Fig. 2). For the three mangrove trees ( $R$. mangle, $L$. racemosa, and $P$. officinalis), $\mathrm{S} / \mathrm{V}$ ratios were higher in woody tissues than in leaf tissues, ranging from 1.07 to 1.82 and from 0.57 to 1.3 , respectively. This ratio was close to 0 for the fern Acrostichum and was equal to 1.37 for Cladium (Fig. 2). Additionally, the acid-toaldehyde ratios for both the vanillic and syringic units were higher in leaves than in woody tissues for Rhizophora and Laguncularia, but were similar in the wood and leaves of Acrostichum and Pterocarpus (Table 1).

The woods of all the mangrove species were almost twice as rich in carbohydrates as their leaves, i.e. from 32.6 to $50.6 \mathrm{mmol} \mathrm{TCOH}-\mathrm{C} / 100 \mathrm{mmol}$ TOC and from 15.0 to $32.1 \mathrm{mmol}$ TCOH-C/100 mmol TOC, respectively (Table 1). The fern Acrostichum was the richest in carbohydrates. Glucose was the most abundant neutral sugar in all plants, representing 
between 26 and $67 \%$ of total sugars in leaves and between 47 and $71 \%$ in wood. Ribose and the deoxy sugars (rhamnose and fucose) were the least abundant monomers, representing generally less than $5 \%$ of total carbohydrates. Leaves were characterized by a higher content in hemicellulosic carbohydrates than wood, e.g. up to $81 \%$ of total carbohydrates in the leaves of Rhizophora. In addition to glucose, the 3 mangrove tree leaves were also characterized by high proportions, first of arabinose and second of galactose. Conversely, woody tissues were richer in xylose than leaves, with values ranging from 13 to $22 \%$ and from 5 to $13 \%$, respectively.

\subsection{Distribution of carbohydrates and lignin-derived phenols in mangrove sediments}

In the studied mangrove sediments, TOC varied between 17 and 48\%, with higher values on the landward side of the mangrove (Lallier-Vergès et al., 1998). Except beneath the $R$. mangle stands, TOC decreased downwards in the upper 40 to $60 \mathrm{~cm}$ and then increased up to values as high as those measured in the upper sediment (Fig. 3). Total lignin concentrations ranged between 8 and $78 \mathrm{mg} \mathrm{g}^{-1}$ (Fig. 4), $\mathrm{X}_{\text {lignin }}$ representing between 1.8 and $10 \%$ of TOC (Table 2). The highest concentrations were found in the upper sediment beneath Rhizophora and Laguncularia and in the sample taken at $132 \mathrm{~cm}$ depth beneath Cladium, i.e. the deepest one. Total lignin displayed the same evolution pattern as TOC, and the proportion of organic carbon (OC) from lignin in the TOC was also higher at depth than at mid-core. For instance beneath Pterocarpus, OC from lignin represented 1.8 and 5.5\% of TOC at 103 and $143 \mathrm{~cm}$ depth, respectively. The proportions of lignin units in mangrove sediments varied as follows: vanillic (27 to $78 \%$ ), syringic (11 to $37 \%$ ), and cinnamic units (2 to $24 \%$ ) (Table 2 ). S/V ranged between 0.4 and 0.9 except beneath Acrostichum, where they were very low, close to 0.15 in the upper core (Fig. 5). C/V ratios ranged between 0.06 and 0.69 , the lowest values having also been measured beneath Acrostichum. Beneath Rhizophora, Laguncularia and Cladium, the upper core was characterized by an increase in $\mathrm{C} / \mathrm{V}$ ratios with increasing depth and a slight increase in S/V ratios (Fig. 5). Beneath Pterocarpus, the upper part of the core was characterized by a slight decrease in the $\mathrm{C} / \mathrm{V}$ ratio and a slight increase in the $\mathrm{S} / \mathrm{V}$ ratio with depth. When examined in a $\mathrm{C} / \mathrm{V}$ vs. $\mathrm{S} / \mathrm{V}$ diagram, the signatures of the deeper samples, appear closest to those of the upper core than to those taken at mid-core, whatever the sampling site (Fig. 5). Ad/Al ratios of both syringic and vanillic units were lower than 1 in every sample except below $1 \mathrm{~m}$ depth beneath Pterocarpus (Table 2). Beneath Laguncularia, Acrostichum, and Cladium, these ratios increased slightly with depth in the upper core section and then decreased in the layers that were characterized by higher TOC values (Table 2).

Total carbohydrate concentrations ranged between 16 and $88 \mathrm{mg} \mathrm{g}^{-1}$ (Fig. 4), and OC from carbohydrates represented between 2 and $9 \%$ of TOC contents (Table 3 ). In all cores, total carbohydrate concentrations as well as their OC contribution to the TOC were at a maximum in the upper $1 \mathrm{st} \mathrm{cm}$ and displayed the same downward evolution pattern as TOC (Fig. 4; Table 3 ). For instance beneath L. racemosa, OC from carbohydrates represented 2.1 and $3.9 \%$ of TOC at 65 and $178 \mathrm{~cm}$ depth, respectively (Table 3 ). The proportions of neutral sugars in the sediment varied as follows: glucose ( 27 to $57 \%$ ), arabinose ( 8 to $26 \%$ ), xylose ( 7 to $17 \%$ ), galactose (6 to $15 \%$ ), rhamnose ( 5 to $15 \%$ ), mannose (3 to $13 \%$ ), fucose (3 to $6 \%$ ) and ribose $(<2 \%)$ (Table 3$)$. Beneath $R$. mangle, the sediments were characterized by the highest concentrations in xylose and rhamnose. Conversely, on the landward side of the mangrove, the upper sediment was characterized by the highest concentrations in galactose. No specific trend with depth could be observed for any neutral sugar. However, the ratios between xylose 
and rhamnose decreased with depth in the upper core and then increased to reach the highest values in layers that were characterized by higher TOC contents (Fig. 6).

\section{Discussion}

\subsection{Mangrove tissues signature}

In recent decades, lignin has often been used to trace the input of higher plant remains in riverine, coastal and marine environments ([Hedges and Mann, 1979b], [Hedges et al., 1986], [Dittmar et al., 2001] and [Bianchi et al., 2007]). Some authors have examined the lignin content of possible source material such as the leaves of various mangrove species: Rhizophora (Benner et al., 1990), Avicennia (Opsahl and Benner, 1995), Avicennia, Rhizophora and Laguncularia (Dittmar and Lara, 2001), and Avicennia, Rhizophora, Laguncularia, Crenea, and Acrostichum (Marchand et al., 2005). Leaves of Rhizophora and Laguncularia from Guadeloupe exhibit a typical vascular-plant lignin signature (Hedges and Mann, 1979a) and present a lignin yield close to $1 \mathrm{mmol}$ phenolic C/100 mmol TOC, similar to values from mangrove leaves collected in the Bahamas (Benner et al., 1990), Brazil (Dittmar and Lara, 2001), and French Guiana (Marchand et al., 2005). In contrast to leaves, mangrove wood compositions have seldom been investigated ([Opsahl and Benner, 1995] and [Marchand et al., 2005]). The woody tissues of these species are 4 times richer in lignin than their leaves and contain only a few cinnamic units thus inducing low $\mathrm{C} / \mathrm{V}$ ratios. Such a composition, which is typical for angiosperm woody tissues ([Hedges and Ertel, 1982] and [Ertel and Hedges, 1984]), is consistently supported by previous results obtained by Opsahl and Benner (1995) and Marchand et al. (2005) for Avicennia wood. While we observed that Pterocarpus woody tissues have the same composition as Rhizophora and Laguncularia woods, the low content in cinnamic unit of its leaves is surprising. As observed in other mangroves ([Benner et al., 1990], [Dittmar and Lara, 2001] and [Marchand et al., 2005]), the $\mathrm{C} / \mathrm{V}$ ratios of mangrove leaves are higher than those of other dicotyledonous angiosperm leaves. S/V ratios of Rhizophora and Laguncularia leaves are in the same range as in Brazil (Dittmar and Lara, 2001) or in French Guiana mangroves (Marchand et al., 2005). Vanillic and syringic acid-to-aldehyde ratios determined for the leaves of these mangrove species are relatively high. They are also high for the woods, whereas Marchand et al. (2005) observed that mangrove woody tissues were characterized by very low vanillic acid to aldehyde ratios. Conversely to the signature of these mangrove trees, the fern Acrostichum is characterized by low $\mathrm{C} / \mathrm{V}$ and $\mathrm{S} / \mathrm{V}$ ratios, both close to 0.1 (Fig. 2). The dominance of vanillic units in Acrostichum is characteristic of the lignin composition of Pteridophytes. Accordingly, Logan and Thomas (1985) observed that vanillin represented 98\% of total aldehydes in 5 out of 6 analysed ferns. Finally, Cladium exhibits a typical angiosperm signature close to that of mangrove tree leaves.

Studies dealing with the carbohydrate composition of mangrove tissues are relatively scarce ([Moers et al., 1990], [Benner et al., 1990], [Opsahl and Benner, 1999] and [Marchand et al., 2005]). In our study, total carbohydrate yields, with higher values in wood than in leaves, are in agreement with data previously obtained by Marchand et al. (2005) in French Guiana, except for Acrostichum for which higher carbohydrate concentrations were found in the present work. Wood and leaves can be differentiated by their carbohydrate contents. Leaves were always richer than wood in hemicellulosic carbohydrates and especially in galactose. Accordingly, Benner et al. (1990) reported that Rhizophora leaves contained 15\% of galactose, and Moers et al. (1990) found only 5\% of galactose in Rhizophora wood, which is 
consistent with our own findings. Conversely, high xylose contents, $(>13 \%)$ appear characteristic of wood. The high xylose contents determined by Opshal and Benner (1999) and Moers et al. (1990) for Avicennia and Rhizophora wood (14 and 24\% respectively), are in full agreement with our data.

\subsection{Lignin and carbohydrates in mangrove sediments: a two-step evolution of organic deposits}

The mangrove studied sediments present very high organic contents. They are also characterized by unusual depth profiles, beginning with a classical downward decrease expressing progressive degradation of organic matter, but at depth this profile is followed by a rather surprising increasing trend. This peculiar trend is opposite to usual decay profiles, as described in other mangrove swamps (Marchand et al., 2003).

\subsubsection{Sources vs. diagenesis in the upper layer}

Along the sea-land transect, xylose and galactose present an opposite trend. The highest xylose concentrations were found beneath Rhizophora, the most seaward mangrove plant, whereas the highest galactose content was measured beneath Pterocarpus, the most landward plant species. In plant tissues, a high xylose content is a characteristic of wood whereas galactose is more abundant in leaves. Cowie and Hedges (1984) suggested that the sum of arabinose and galactose can be used to distinguish inputs of non-woody vascular plant tissues. Accordingly, the higher galactose contents determined on the landward side of the studied transect may reflect an accumulation of leaf litter, while on the seaward side the contribution of the root system to the organic accumulation may be responsible for its specific sugar composition. Additionally, the high proportion of lignin normalized to TOC recorded in the upper part of the cores collected beneath Rhizophora and Laguncularia confirms the important contribution of woody tissues to the OM. It must be underlined that the organic accumulation was higher beneath Cladium and Pterocarpus. This probably results from the fact that in contrast to the most seaward mangroves that were daily flushed by tides, mangroves developing on the landward side were not, thus allowing an accumulation of leaf litter and hence higher galactose contents.

In the upper cores, total carbohydrate concentrations decrease with depth as well as their proportions normalized to TOC. OC from carbohydrates represents between 15 and $50 \%$ of TOC in the mangrove plant species but less than $9 \%$ in the mangrove sediments, whatever the forest zone. This result highlights the reactivity of carbohydrates relative to bulk OC as observed in other swamps where degradation of polysaccharides appeared to be very efficient even in waterlogged sediments ([Cowie and Hedges, 1984], [Stout et al., 1988], [Moers et al., 1990] and [Marchand et al., 2005]). Although the present results show that the decomposition of carbohydrates is continuous within the sediment, at least $50 \%$ of these compounds were already degraded in the litter, before being readily incorporated to the sediment. The decomposition of carbohydrates in the litter first occurred through leaching processes (Benner et al., 1990). The substance loss between the higher plant sources and the sediments might even have been more important than it appears at first sight since part of the sedimentary hemicellulosic carbohydrates may have been neo-synthesized in situ by micro-organisms or expelled by higher plants through their root systems (Cowie and Hedges, 1984). In fact, the studied mangrove sediments here are characterized by higher contents in deoxy sugars (rhamnose and fucose) than mangrove plants. Hedges et al. (1988) showed that deoxy sugars could be derived from bacteria, and later Moers et al. (1990) demonstrated that they can 
contribute significantly to mangrove peat. In addition, the ratio between xylose and rhamnose decreases in the upper part of the cores beneath all the mangrove stands (Fig. 6), thus highlighting increasing bacterial contribution to total carbohydrates with increasing depth.

OC from lignin-derived phenols ranges from 1 to $10 \%$ TOC in mangrove tissues and varies between 2 and $10 \%$ in mangrove sediments, highlighting the relative stability of these compounds compared to carbohydrates and bulk OC ([Benner et al., 1984a], [Benner et al., 1984b], [Hedges et al., 1985], [Cowie et al., 1992], [Dittmar and Lara, 2001] and [Marchand et al., 2005]). Nevertheless, like carbohydrates, phenol concentrations decrease with depth in the upper cores, thus highlighting lignin decomposition. Vanillic units are predominant in the mangrove sediments where they range between 27 and $78 \%$ of total phenols, whereas in the plant tissues they are dominant only in the fern. As a consequence, S/V ratios are lower in sediments than in plants. These results might indicate a preferential degradation of syringic phenols by decomposers, with the elimination of one of the 3- or 5-methoxyl group, thus entailing an increase in vanillic units at the expense of syringic ones ([Hedges et al., 1988] and [Goñi et al., 1993]). This lignin decomposition pathway does not seem to be common in all mangroves. For example, in Brazilian mangroves, Dittmar and Lara (2001) found relatively constant $\mathrm{S} / \mathrm{V}$ values, similar to those of leaf litter. They suggested a similar diagenetic reactivity for syringic and vanillic moieties in anoxic mangrove sediments. The Guadeloupe mangrove upper sediments are also highly depleted in cinnamic phenols relative to vanillic phenols, and thus characterized by very low $\mathrm{C} / \mathrm{V}$ ratios. On the one hand, these low $\mathrm{C} / \mathrm{V}$ ratios may partly result from the relative reactivity of the various phenols. Dittmar and Lara (2001) also observed low C/V ratios and, referring to the work of Benner et al. (1990) and Opsahl and Benner (1995), suggested a preferential loss of cinnamic acids known to be rather peripheral to the lignin core to which they are linked by a rather labile ester bond. On the other hand, low $\mathrm{C} / \mathrm{V}$ ratio values may also result from the introduction of root-derived $\mathrm{OM}$, which originally has low $\mathrm{C} / \mathrm{V}$ ratios, as already observed in French Guiana mangroves (Marchand et al., 2005). Finally, the low $\mathrm{C} / \mathrm{V}$ and $\mathrm{S} / \mathrm{V}$ ratios measured in the upper sediment level beneath Acrostichum, more probably reflect some source variation than a diagenetic evolution, since this plant species is characterized by the dominance of the vanillic unit (Table 1). The $\mathrm{Ad} / \mathrm{Al}$ ratios of both syringic and vanillic units are low and close to those of mangrove tissues, except beneath Pterocarpus, where these ratios are relatively high. Low Ad/Al ratios appear typical for lignin decomposition under anoxic conditions. Reversely, high Ad/Al ratio values result from an oxidation of the propyl chain of lignin units, typical for lignin decomposition under oxic conditions ([Hedges and Ertel, 1982] and [Ertel and Hedges, 1984]). Thus, the rationale for these contrasting results might be that Rhizophora and Laguncularia forests develop under the influence of marine water whereas Pterocarpus forest develops under the influence of fresh water and is less frequently inundated by the sea. This difference induces an evolution in the redox conditions in the sediments, with increasing distance from the sea (Fig. 7). In the mangroves of Guadeloupe, seaward sediments are the site for anoxic conditions and organic decomposition processes mainly driven by sulfate reduction processes, as highlighted by high sulfur contents (Lallier-Vergès et al., 1998). Conversely on the landward side, mangrove sediments are oxygenated and have low sulfur contents (Lallier-Vergès et al., 1998). These various observations support the idea that different processes of lignin decomposition occur within the sediments under the various mangrove forests, as a result of their location in the swamp and the respective influence and frequency of fresh and salt water input. 


\subsubsection{Preservation of $\mathrm{OM}$ at depth in relationship with past water-table variation}

In previous work (Lallier-Vergès et al., 1998), we observed that mangrove sediments from Le Grand Cul-de-Sac Marin were characterized by higher TOC contents at depth than in the upper levels. The deep organic-rich layer had lower $\partial^{13} \mathrm{C}$ values and higher $\mathrm{C} / \mathrm{N}$ ratios, highlighting the important contribution of higher plants to its OM. For instance, beneath Laguncularia, ${ }^{13} \mathrm{C}$ values decreased from $-27 \%$ to $-28 \%$, and $\mathrm{C} / \mathrm{N}$ increased from 17 to 43 (Lallier-Vergès et al., 1998). The present molecular approach provides a more precise description of this organic accumulation. First, it presents higher xylose over rhamnose ratio values than the upper layers (Fig. 6) thus indicating a large contribution from higher plants. Then, the proportion of OC from carbohydrates and phenols in the TOC was also found to be higher in this buried layer compared to the overlying deposits (Table 2 and Table 3). Finally, when examined in a $\mathrm{C} / \mathrm{V}$ vs. S/V diagram (Fig. 5), the chemical signatures of samples from this deep layer were closer to those taken in the upper sediments than to those taken at midcore. Consequently, the OM of this layer is chemically well-preserved, nearly as well as in litter. Accordingly, while the organic content of the upper sediment certainly resulted from an in situ accumulation of the mangrove system during the last millennia (Lallier-Vergès et al., 1998), a simple aggradational process cannot explain such an OM preservation at depth. We assume herein that only rapid and complete water flooding of the coastal mangrove deposit may account for this exceptional chemical preservation. Such organic matter compositional variations have already been evidenced in ancient sedimentary formations. Accordingly, the vertical and lateral distribution of organic components (macerals) in sequential coal-bearing strata from Campanian coastal deposits exhibited differential organic preservation, which was interpreted as the consequence of very short-term base level changes of probable climatic origin (Buillit et al., 2002). Since climate forcing cannot be invoked during the last two millennia in order to explain a rapid uplift of the water-table, we surmise that the specific geodynamic context of Grande Terre Island could be the main driving force for such a watertable variation. Indeed, we speculate that the intense coupled volcanic and seismic sensitivity of the island ([Feuillet et al., 2001], [Feuillet et al., 2002] and [Feuillet et al., 2004]) might have induced the modification in water tables resulting in the flooding of the most littoral organic formations and thus the preservation of these compounds.

\section{Conclusions}

This study has allowed us first to precisely define the lignin and carbohydrate composition of some mangrove plant tissues, then to confirm the potential use of some of these compounds as source tracers, and finally to evidence the well-preserved character of the OM in a buried organic-rich layer.

1) Mangrove trees (Rhizophora, Pterocarpus, and Laguncularia) exhibited a typical angiosperm woody tissues signature rich in lignin-derived oxidation products, with very few cinnamic units and high xylose contents. Concerning leaf tissues, $\mathrm{C} / \mathrm{V}$ ratios were confirmed to be higher than for other dicotyledonous angiosperm leaves, except for Pterocarpus, which contains surprisingly low amounts of cinnamic units. The leaves were also characterized by a high content in hemicellulosic carbohydrates, especially galactose. The fern Acrostichum was characterized by a very high dominance of vanillic units, while Cladium had a signature close to that of mangrove tree leaves. A rather high content in deoxy sugars (rhamnose and fucose) in mangrove sediments compared to mangrove plants might indicate their in situ production by bacteria thriving at the expense of higher plant remains. Accordingly, decreasing xylose over rhamnose ratios in the upper part of the cores probably highlights an increasing 
contribution of bacterial sugars to total carbohydrates. Finally, the opposite evolution of xylose and galactose contents in upper sediments from the seaward to the landward sides evidences their ability to trace leaf and woody tissues. The farther from the sea, the higher the accumulation of leaf litter, and the higher the galactose content. Conversely, on the seaward side, the main contributor of organic matter was the root system, as highlighted by high xylose contents.

2) Concerning the behavior of the studied compounds regarding diagenesis, our results show the reactivity of carbohydrates relative to bulk OC, with at least $50 \%$ of carbohydrates being readily degraded before being incorporated to the sediment. Conversely, lignin-derived phenols were lost at a similar or lower rate than bulk OC. Various decomposition processes have been evidenced for phenols. In most mangroves, decomposers preferentially utilized syringic phenols, and eliminated the 3- and/or 5-methoxyl group. Beneath the landward forests, processes of lignin decomposition under oxic conditions were also observed, as evidenced by high $\mathrm{Ad} / \mathrm{Al}$ ratios. As a consequence, the position of the mangrove stand in the swamp regarding the fresh and saline water inputs appears predominant in OM decay processes.

3) A deep organic-rich layer has been confirmed to derive from higher plants by high xylose over rhamnose ratio values. Additionally, the proportion of $\mathrm{OC}$ from carbohydrates and phenols in TOC, and the $\mathrm{C} / \mathrm{V}$ and $\mathrm{S} / \mathrm{V}$ signatures of this layer evidences the chemically wellpreserved character of this OM. We speculate that a catastrophic event linked to regional geodynamics may have induced modifications in the water-table, leading to the rapid and complete flooding of mangrove swamps, and thus to the preservation of these compounds.

\section{Acknowledgments}

The authors would like to thank F. Baltzer and S. Lallier for their valuable assistance on field. C. Hatton and O. Sagot are gratefully acknowledged for their participation in the analyses of the chemical compounds. Recommendations of D. Rickard and of two anonymous reviewers were much appreciated.

\section{References}

Alongi et al., 2000 D.M. Alongi, F. Tirendi and B.F. Clough, Below-ground decomposition of organic matter in forests of the mangrove Rhizophora stylosa and Avicennia marina along the arid coast of Western Australia, Aquat. Bot. 68 (2000), pp. 97-122

Benner et al., 1984a R. Benner, A.E. Maccubin and R.E. Hodson, Anaerobic biodegradation of the lignin and polysaccharide components of lignocellulose and synthetic lignin by sediment microflora, Appl. Environ. Microbiol. 47 (1984), pp. 998-1004.

Benner et al., 1984b R. Benner, S.Y. Newell, A.E. Maccubin and R.E. Hodson, Relative contributions of bacteria and fungi to rates of degradation of lignocellulosic detritus in salt marsh sediments, Appl. Environ. Microbiol. 48 (1984), pp. 36-40.

Benner et al., 1990 R. Benner, K. Weliky and J.I. Hedges, Early diagenesis of mangrove leaves in a tropical estuary: molecular-level analyses of neutral sugars and lignin derived phenols, Geochim. Cosmochim. Acta 54 (1990), pp. 1991-2001.

Bianchi et al., 1999 T.S. Bianchi, M. Argyrou and H.F. Chippett, Contribution of vascularplant carbon to surface sediments across the coastal margin of Cyprus (eastern Mediterranean), Org. Geochem. 30 (1999), pp. 287-297. 
Bianchi et al., 2007 T.S. Bianchi, L.A. Wysocki, M. Stewart, T.R. Filley and B.A. McKee, Temporal variability in terrestrially-derived sources of particulate organic carbon in the lower Mississippi River and its upper tributaries, Geochim. Cosmochim. Acta 71 (2007), pp. 44254437.

Bouillon et al., 2003 S. Bouillon, F. Dahdouh-Guebas, A.V.V.S. Rao, N. Koedam and F. Dehairs, Sources of organic carbon in mangrove sediments: variability and possible ecological implications, Hydrobiology 495 (2003), pp. 33-39.

Bouillon et al., 2008 S. Bouillon, A.V. Borges, E. Castañeda-Moya, K. Diele, T. Dittmar, N.C. Duke, E. Kristensen, S.Y. Lee, C. Marchand, J.J. Middelburg, V.H. Rivera-Monroy, T.J. Smith III and R.R. Twilley, Mangrove production and carbon sinks: a revision of global budget estimates, Global Biogeochem. Cycling 22 (2008), p. GB2013.

Buillit et al., 2002 N. Buillit, E. Lallier-Vergès, B. Pradier and G. Nicolas, Coal petrographic genetic units in deltaic-plain deposits of the Campanian Mesa Verde Group (New Mexico, USA), Int. J. Coal Geol. 51 (2002), pp. 93-110.

Chen and Twilley, 1999 R. Chen and R.R. Twilley, A simulation model of organic matter and nutrient accumulation in mangrove wetland soils, Biogeochemistry 44 (1999), pp. 93-118. Chmura et al., 2003 G.L. Chmura, S.C. Anisfeld, D.R. Cahoon and J.C. Lynch, Global carbon sequestration in tidal, saline wetland soils, Global Biogeochem. Cycles 17 (4) (2003), p. 1111. Cowie and Hedges, 1984 G.L. Cowie and J.I. Hedges, Carbohydrate sources in a coastal marine environment, Geochim. Cosmochim. Acta 48 (1984), pp. 2075-2087.

Cowie et al., 1992 G.L. Cowie, J.I. Hedges and S.E. Calvert, Sources and reactivities of amino acids, neutral sugars and lignin in an intermittently anoxic marine environment, Geochim. Cosmochim. Acta 56 (1992), pp. 1963-1978.

Dittmar and Lara, 2001 T. Dittmar and R.J. Lara, Molecular evidence for lignin degradation in sulfate reducing mangrove sediments (Amazonia, Brazil), Geochim. Cosmochim. Acta 74 (2001), pp. 1417-1428.

Dittmar et al., 2001 T. Dittmar, R.J. Lara and G. Kattner, River or mangrove? Tracing major organic matter sources in tropical Brazilian coastal waters, Mar. Chem. 73 (2001), pp. 253271.

Ertel and Hedges, 1984 J.R. Ertel and J.I. Hedges, The lignin component of humic substances: distribution among soil and sedimentary humic, fulvic and base insoluble fractions, Geochim. Cosmochim. Acta 48 (1984), pp. 2065-2074.

Feller et al., 1990 C. Feller, M. Fournier, D. Imbert, C. Caratini and L. Martin, Datations ${ }^{14} \mathrm{C}$ et palynologie d'un sédiment tourbeux continu (0-7 m) dans la mangrove de Guadeloupe (F.W.I.). Résultats préliminaires, Evolution des Littoraux de Guyane et de la Zone Caraïbe Méridionale Pendant le Quaternaire, ORSTOM, Paris (1990), pp. 193-202.

Feuillet et al., 2001 N. Feuillet, I. Manighetti and P. Tapponnier, Extension active perpendiculaire à la subduction dans l'arc des Petites Antilles (Guadeloupe, Antilles françaises) Active arc-transverse normal faulting in Guadeloupe (French Lesser Antilles), $C$. R. Acad. Sci. Ser. IIA - Earth Planet. Sci. 333 (9) (2001), pp. 583-590.

Feuillet et al., 2002 N. Feuillet, I. Manighetti, P. Tapponnier and E. Jacques, Arc parallel extension and localization of volcanic complexes in Guadeloupe, Lesser Antilles, J. Geophys. Res. 107 (2002), p. B122331.

Feuillet et al., 2004 N. Feuillet, P. Tapponnier, I. Manighetti, B. Villemant and G.C.P. King, Differential uplift and tilt of Pleistocene reef platforms and Quaternary slip rate on the MornePiton normal Fault (Guadeloupe, FWI), J. Geophys. Res. 109 (2004), p. B02404.

Goñi and Hedges, 1995 M.A. Goñi and J.I. Hedges, Sources and reactivities of marinederived organic matter in coastal sediments as determined by alkaline $\mathrm{CuO}$ oxidation, Geochim. Cosmochim. Acta 59 (1995), pp. 2965-2981. 
Goñi et al., 1993 M.A. Goñi, B.N. Nelson, R.A. Blanchette and J.I. Hedges, Fungal degradation of wood lignins: geochemical perspectives from $\mathrm{CuO}$-derived phenolic dimers and monomers, Geochim. Cosmochim. Acta 57 (1993), pp. 3985-4002.

Hedges and Mann, 1979a J.I. Hedges and D.C. Mann, The characterization of plant tissues by their lignin oxidation products, Geochim. Cosmochim. Acta 43 (1979), pp. 1803-1807. Hedges and Mann, 1979b J.I. Hedges and D.C. Mann, The lignin geochemistry of marine sediments from the southern Washington coast, Geochim. Cosmochim. Acta 43 (1979), pp. 1809-1818.

Hedges and Ertel, 1982 J.I. Hedges and J.R. Ertel, Characterization of lignin by capillary gas chromatography of cupric oxide oxidation products, Anal. Chem. 54 (1982), pp. 1174-1178. Hedges et al., 1985 J.I. Hedges, G.L. Cowie, J.R. Ertel, R.J. Barbour and P.G. Hatcher, Degradation of carbohydrates and lignins in buried woods, Geochim. Cosmochim. Acta 49 (1985), pp. 701-711.

Hedges et al., 1986 J.I. Hedges, W.A. Clark, P.D. Quay, J.E. Richey, A.H. Devol and U.M. Santos, Composition and fluxes of particulate organic material in the Amazon River, Limnol. Oceanogr. 31 (1986), pp. 717-738.

Hedges et al., 1988 J.I. Hedges, R.A. Blanchette, K. Weliky and A.H. Devol, Effect of fungal degradation on the $\mathrm{CuO}$ oxidation products of lignin: a controlled laboratory study, Geochim. Cosmochim. Acta 52 (1988), pp. 2717-2726.

Kristensen et al., 2008 E. Kristensen, S. Bouillon, T. Dittmar and C. Marchand, Organic carbon dynamics in mangrove ecosystem, Aquat. Bot. 89 (2) (2008), pp. 210-219.

Lallier-Vergès et al., 1998 E. Lallier-Vergès, B.P. Perrussel, J.-R. Disnar and F. Baltzer, The relationship between environmental conditions and the diagenetic evolution of organic matter derived from higher plant in a present mangrove swamp system (Guadeloupe, French West Indies), Org. Geochem. 29 (1998), pp. 1663-1686.

Lallier-Vergès et al., 1999 E. Lallier-Vergès, J.-R. Disnar, O. Maman, O. Sagot, B. Guillet and P. Albéric, Phenols and sugars in hydromorphous soils from Guadeloupe (FWI):

relationships with vegetal precursors and degradation conditions. In: Tübitak, Editor, EAOG Meeting 2, Marama Research Center (1999), pp. 565-566.

Logan and Thomas, 1985 K. Logan and B.A. Thomas, Distribution of lignin derivatives in plants, New Phytol. 99 (1985), pp. 571-585.

Maman et al., 1996 O. Maman, F. Marseille, B. Guillet, J.-R. Disnar and P. Morin, Separation of phenolic aldehydes, ketones and acids of lignin by Capillary Zone Electrophoresis, $J$.

Chromatogr. A 755 (1996), pp. 89-97.

Marchand et al., 2003 C. Marchand, E. Lallier-Vergès and F. Baltzer, The composition of sedimentary organic matter in relation to the dynamic features of a mangrove-fringed coast in French Guiana, Estuar. Coastal Shelf Sci. 56 (2003), pp. 119-130.

Marchand et al., 2004 C. Marchand, F. Baltzer, E. Lallier-Vergès and P. Albéric, Pore-water chemistry in mangrove sediments: relationship with species composition and developmental stages (French Guiana), Mar. Geol. 208 (2004), pp. 361-381.

Marchand et al., 2005 C. Marchand, J.-R. Disnar, E. Lallier-Vergès and N. Lottier, Early diagenesis of carbohydrates and lignin in mangrove sediments subject to variable redox conditions (French Guiana), Geochim. Cosmochim. Acta 69 (2005), pp. 131-142.

Miltner et al., 2005 A. Miltner, K.-C. Emeis, U. Struck, T. Leipe and M. Voss, Terrigenous organic matter in Holocene sediments from the central Baltic Sea, NW Europe, Chem. Geol. 216 (2005), pp. 313-328.

Moers et al., 1990 M.E.C. Moers, M. Baas, J.W. De Leuw, J.J. Boon and P.A. Schenck, Occurrence and origin of carbohydrates in peat samples from a red mangrove environment as reflected by abundances of neutral monosaccharides, Geochim. Cosmochim. Acta 54 (1990), pp. 2463-2472. 
Opsahl and Benner, 1995 S. Opsahl and R. Benner, Early diagenesis of vascular plant tissues: lignin and cutin decomposition and biogeochemical implications, Geochim. Cosmochim. Acta 59 (1995), pp. 4889-4904.

Opsahl and Benner, 1999 S. Opsahl and R. Benner, Characterization of carbohydrates during early diagenesis of five vascular plant tissues, Org. Geochem. 30 (1999), pp. 83-94.

Sarkanen and Ludwig, 1971 K.V. Sarkanen and C.H. Ludwig, Lignins: Occurrence, Formation, Structure and Reactions, Wiley-Intersciences, New-York (1971).

Stout et al., 1988 S.A. Stout, J.J. Boon and W. Spackman, Molecular aspects of the peatification and early coalification of angiosperm and gymnosperm woods, Geochim. Cosmochim. Acta 52 (1988), pp. 405-414. 


\section{Figures and Tables}

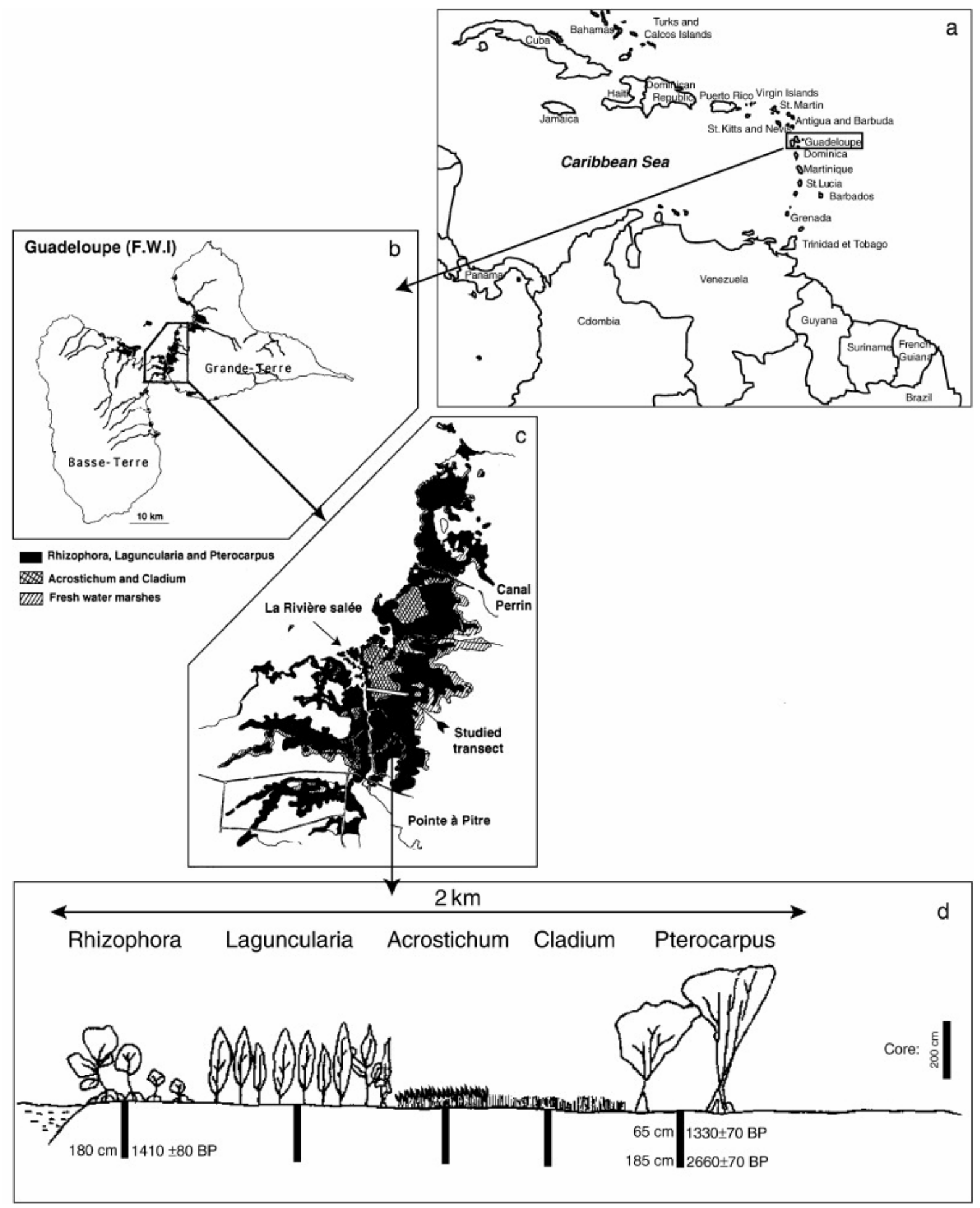

Fig. 1. Maps of the studied area: a) situation of the Guadeloupe Island in the Caribbean Sea; b) situation of the mangrove studied in Guadeloupe; c) surface map of the studied mangrove showing the position of the transect; $d$ ) distribution of the various mangrove species along the transect, and radiocarbon dates (from Lallier-Vergès et al., 1998). 


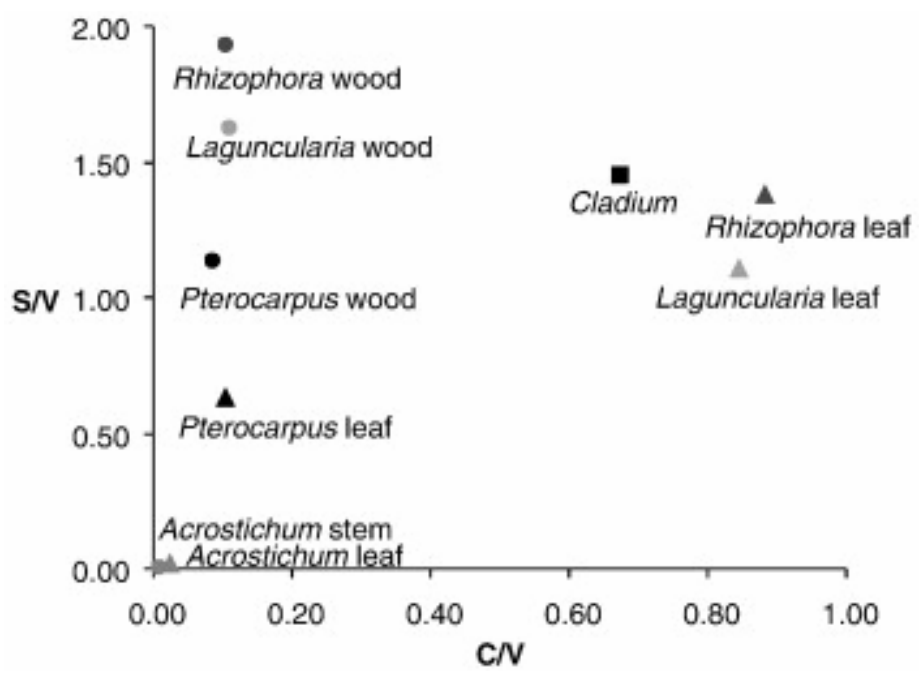

Fig. 2. C/V vs. S/V diagram of the mangrove leaf and woody tissues (Rhizophora mangle, Laguncularia racemosa, Acrostichum aureum, Cladium marescus, and Pterocarpus officinalis).

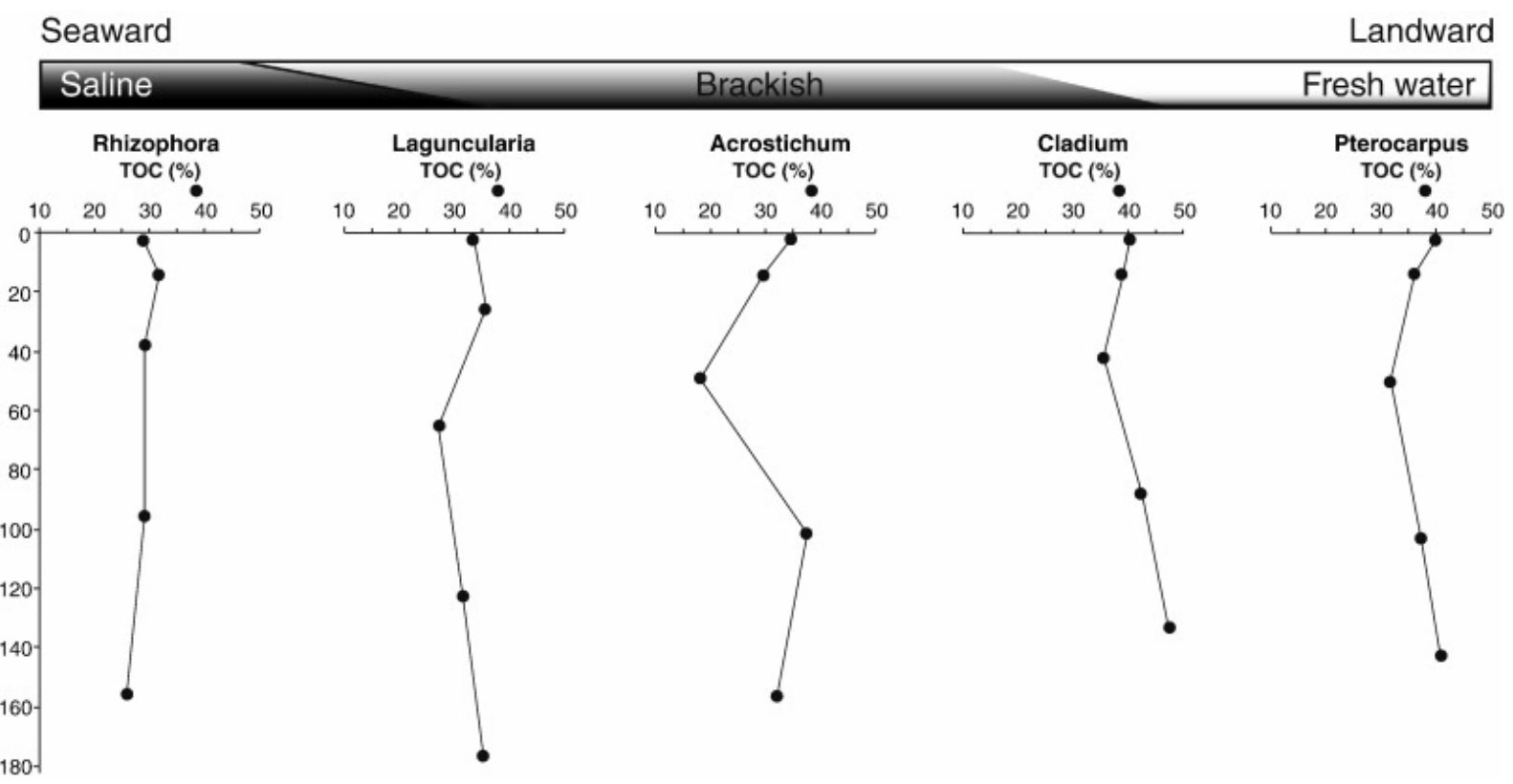

Fig. 3. TOC (\%) depth profiles beneath the different mangrove swamps, i.e. Rhizophora mangle, Laguncularia racemosa, Acrostichum aureum, Cladium marescus, and Pterocarpus officinalis (Data from Lallier-Vergès et al., 1998). 


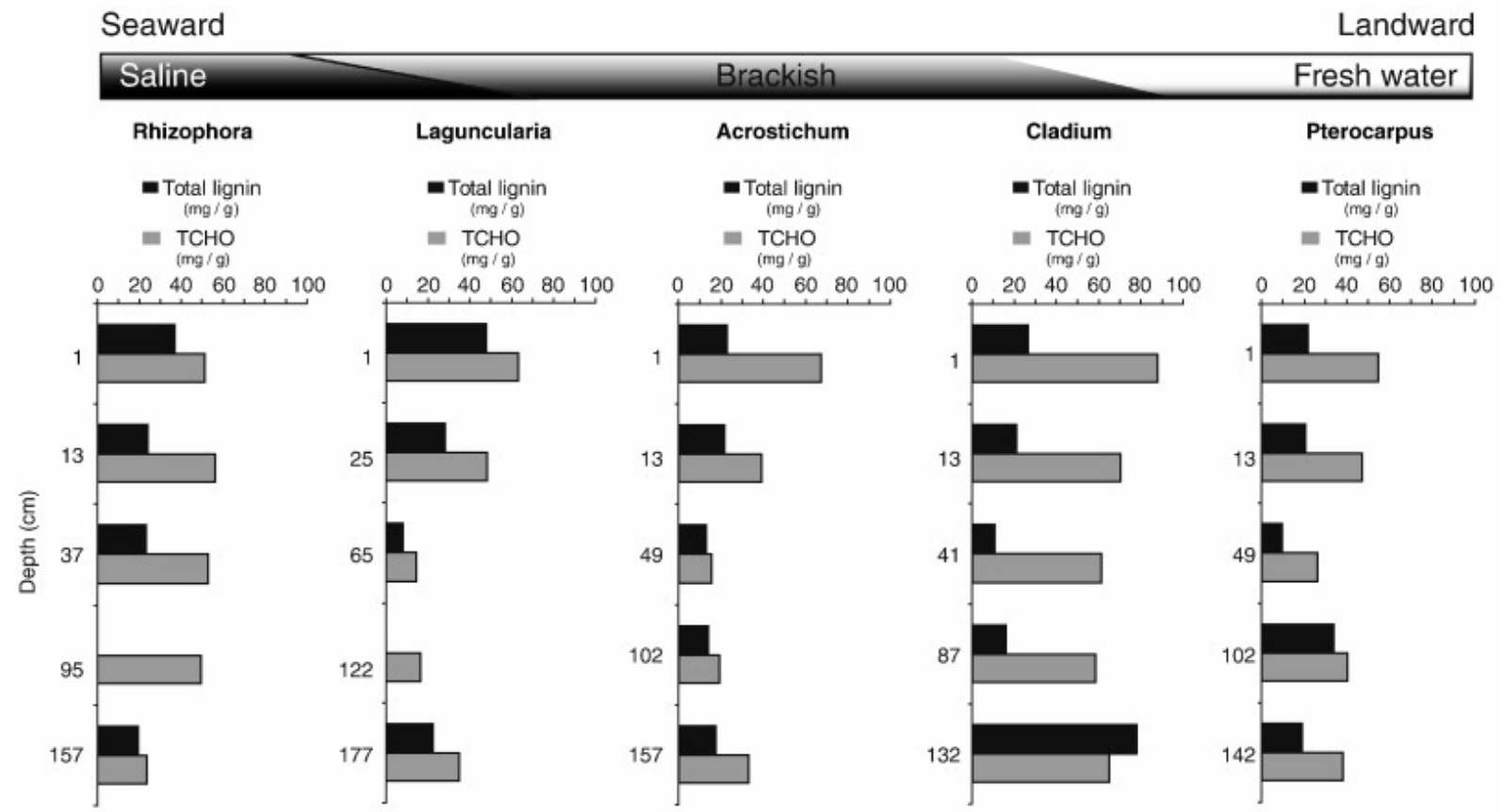

Fig. 4. Depth profiles beneath the different mangrove swamps, i.e. Rhizophora mangle, Laguncularia racemosa, Acrostichum aureum, Cladium marescus, and Pterocarpus officinalis: sum of the vanillic, syringic, and cinnamic phenols (in mg phenol/g sediment), and sum of the eight monosaccharides (TCHO) (ribose, arabinose, xylose, rhamnose, fucose glucose mannose and galactose) in mg sugar/g sediment. (No lignin analyses were performed at $95 \mathrm{~cm}$ depth beneath Rhizophora and at $122 \mathrm{~cm}$ beneath Laguncularia). 

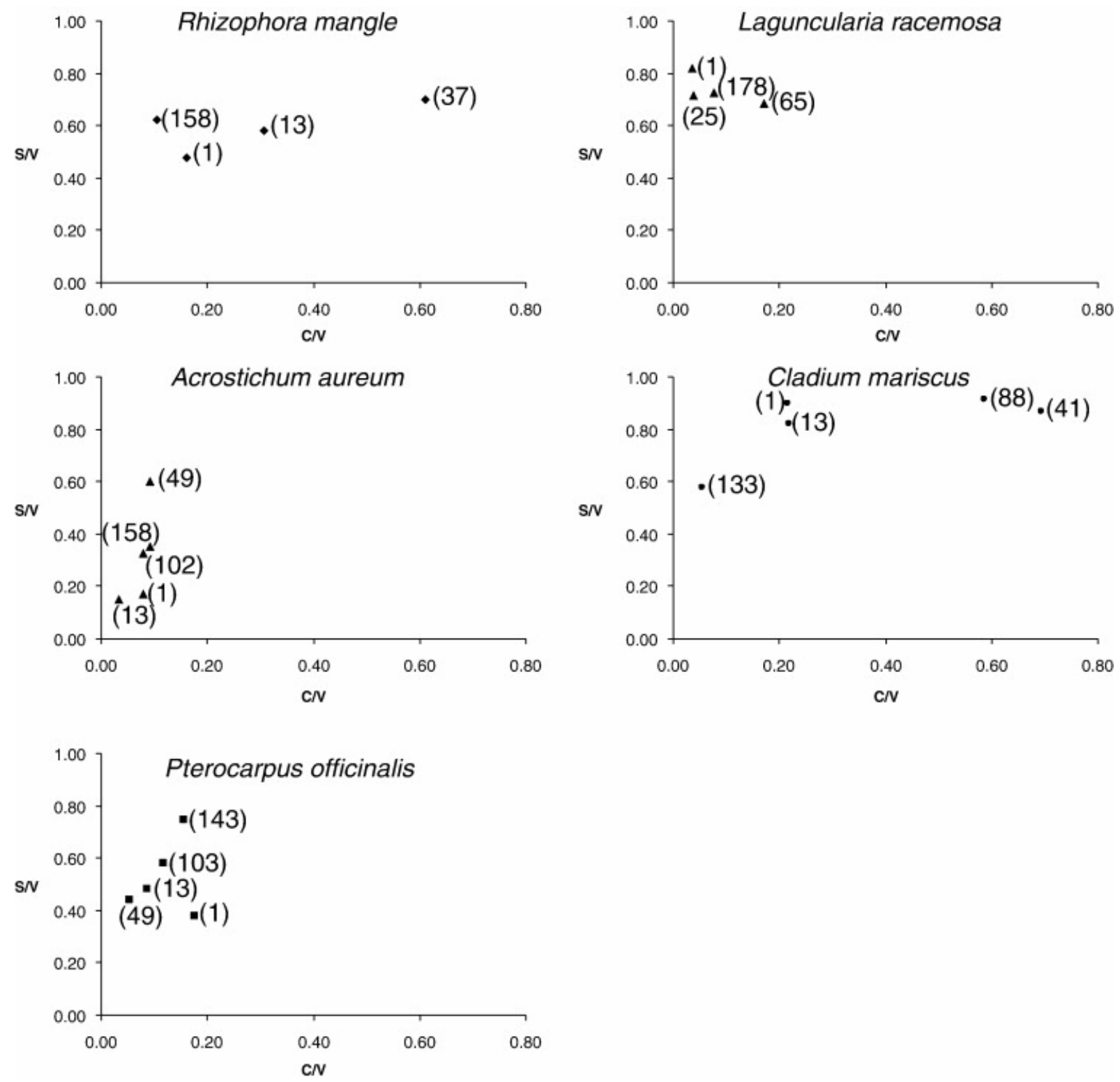

Fig. 5. C/V vs. S/V diagram of sediment samples collected beneath the various mangrove swamps, i.e. Rhizophora mangle, Laguncularia racemosa, Acrostichum aureum, Cladium marescus, and Pterocarpus officinalis. The numbers in bracket indicate the depth of the sample. 


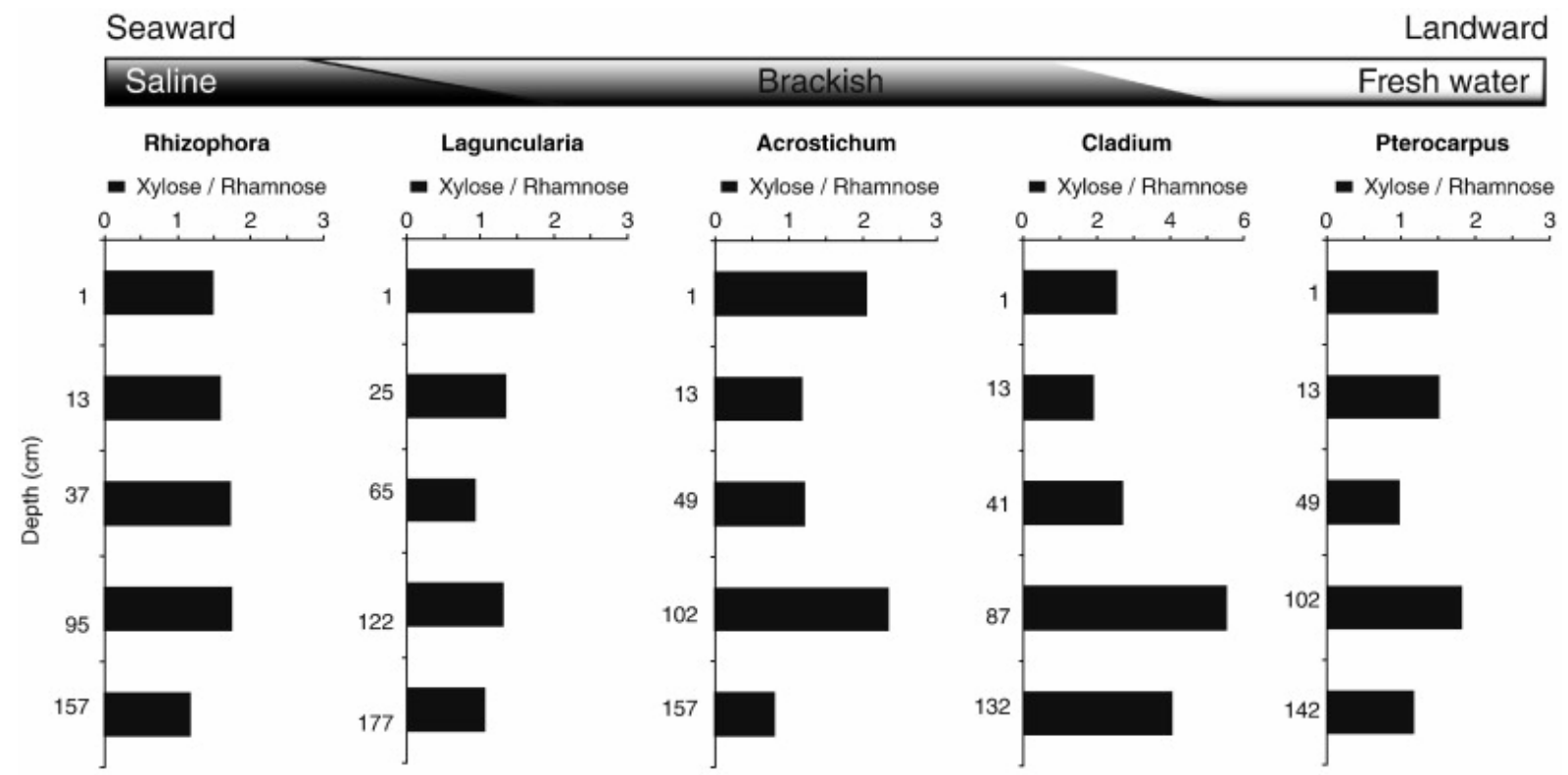

Fig. 6. Depth profiles of xylose over rhamnose ratios beneath the different mangrove swamps, i.e. Rhizophora mangle, Laguncularia racemosa, Acrostichum aureum, Cladium marescus, and Pterocarpus officinalis.

\section{Saline}

Brackish

Fresh water
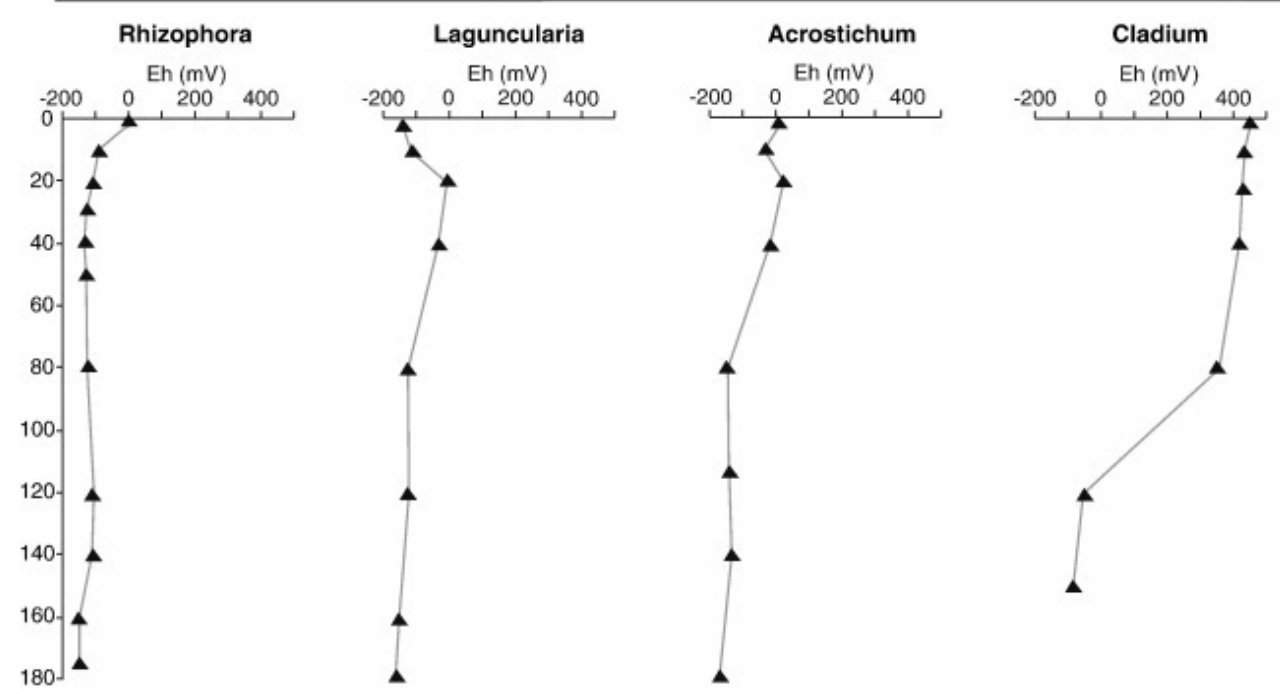

Pterocarpus

Fig. 7. Redox $(\mathrm{mV})$ depth profiles beneath the different mangrove swamps, i.e. Rhizophora mangle, Laguncularia racemosa, Acrostichum aureum, Cladium marescus, and Pterocarpus officinalis (Data from Lallier-Vergès et al., 1998). 
Table 1. : Geochemical characterization of the mangrove plant species developing along the studied transect: percent total organic carbon (TOC); $\mathrm{X}_{\text {lignin }}$ (sum of the vanillic, syringic and cinnamic phenols in mmol phenolic $\mathrm{C} / 100 \mathrm{mmol}$ total OC); $\Sigma 11$ (sum of $\mathrm{X}_{\text {lignin }}$ and $p$ hydroxyl phenols in mmol phenolic $\mathrm{C} / 100 \mathrm{mmol}$ total OC); Vanillic unit, Syringic unit, Cinnamic unit, $p$-hydroxyl unit in \% of total phenols; vanillic acid/vanillin ratios $(\mathrm{Ad} / \mathrm{Al})_{\mathrm{v}}$, syringic acid/syringaldehyde ( $\mathrm{Ad} / \mathrm{Al})_{\mathrm{s}}$; total neutral sugars in mmol TCHO-C/100 mmol total OC; hemicellulosic carbohydrates, total ribose, total arabinose, total xylose, total rhamnose, total fucose, total glucose, total mannose and total galactose in $\%$ of total carbohydrates 


\begin{tabular}{|c|c|c|c|c|c|c|c|c|c|}
\hline & $\begin{array}{l}\text { Rhizophora } \\
\text { leaf }\end{array}$ & $\begin{array}{l}\text { Rhizophora } \\
\text { wood }\end{array}$ & $\begin{array}{l}\text { Laguncularia } \\
\text { leaf }\end{array}$ & $\begin{array}{l}\text { Laguncularia } \\
\text { wood }\end{array}$ & $\begin{array}{l}\text { Acrostichum } \\
\text { leaf }\end{array}$ & $\begin{array}{l}\text { Acrostichum } \\
\text { stem }\end{array}$ & $\begin{array}{l}\text { Cladium } \\
\text { whole } \\
\text { plant }\end{array}$ & $\begin{array}{l}\text { Pterocarpus } \\
\text { leaf }\end{array}$ & $\begin{array}{l}\text { Pterocarpus } \\
\text { wood }\end{array}$ \\
\hline TOC (\%) & 35.82 & 35.53 & 32.16 & 34.49 & 33.48 & 34.76 & 35.66 & 38.86 & 37.54 \\
\hline $\begin{array}{l}\mathrm{X}_{\text {lignin }}(\mathrm{mmol} \text { phenolic } \\
\mathrm{C} / 100 \mathrm{mmol} \text { TOC) }\end{array}$ & 0.95 & 4.16 & 1.09 & 4.63 & 2.34 & 8.88 & 9.85 & 4.99 & 6.57 \\
\hline $\begin{array}{l}\Sigma 11 \text { (mmol phenolic } \\
\text { C/100 mmol TOC) }\end{array}$ & 1.27 & 4.49 & 1.41 & 4.82 & 2.76 & 9.09 & 14.47 & 5.41 & 6.70 \\
\hline $\mathrm{V}(\%)$ & 23.28 & 31.55 & 26.50 & 36.36 & 81.13 & 96.80 & 22.21 & 54.06 & 45.48 \\
\hline $\mathrm{S}(\%)$ & 30.31 & 57.48 & 27.85 & 55.53 & 1.76 & 0.00 & 30.37 & 32.36 & 48.52 \\
\hline $\mathrm{C}(\%)$ & 21.23 & 3.44 & 23.12 & 4.17 & 2.09 & 0.97 & 15.47 & 5.84 & 4.12 \\
\hline $\mathrm{P}(\%)$ & 25.17 & 7.50 & 22.50 & 3.92 & 15.01 & 2.23 & 31.94 & 7.72 & 1.87 \\
\hline$(\mathrm{Ad} / \mathrm{Al})_{\mathrm{v}}$ & 2.41 & 0.62 & 0.64 & 0.32 & 0.98 & 0.95 & 0.42 & 0.47 & 0.47 \\
\hline$(\mathrm{Ad} / \mathrm{Al})_{\mathrm{s}}$ & 1.49 & 0.76 & 1.03 & 0.32 & 0.01 & 0.02 & 0.31 & 0.55 & 0.50 \\
\hline $\begin{array}{l}\text { Total carbohydrates } \\
\text { (mmol TCHO- } \\
\text { C/100 mmol TOC) }\end{array}$ & 20.89 & 33.76 & 15.04 & 32.69 & 32.17 & 50.60 & 28.98 & 21.58 & 42.79 \\
\hline $\begin{array}{l}\text { Hemicellulosic } \\
\text { carbohydrates }(\%)\end{array}$ & 81.46 & 55.72 & 62.67 & 45.98 & 51.62 & 35.97 & 50.70 & 49.22 & 37.56 \\
\hline Total ribose $(\%)$ & 0.69 & 0.77 & 0.80 & 0.67 & 0.18 & 0.24 & 0.60 & 0.32 & 0.30 \\
\hline Total arabinose $(\%)$ & 18.11 & 12.07 & 20.18 & 10.90 & 2.63 & 1.32 & 7.47 & 7.92 & 6.16 \\
\hline Total xylose \%) & 7.05 & 22.04 & 5.62 & 16.85 & 6.61 & 13.20 & 31.19 & 13.07 & 13.82 \\
\hline Total rhamnose $(\%)$ & 11.24 & 3.60 & 4.84 & 2.76 & 2.76 & 0.57 & 0.73 & 3.87 & 2.08 \\
\hline
\end{tabular}




\begin{tabular}{|l|l|l|l|l|l|l|l|l|l|}
\hline & $\begin{array}{l}\text { Rhizophora } \\
\text { leaf }\end{array}$ & $\begin{array}{l}\text { Rhizophora } \\
\text { wood }\end{array}$ & $\begin{array}{l}\text { Laguncularia } \\
\text { leaf }\end{array}$ & $\begin{array}{l}\text { Laguncularia } \\
\text { wood }\end{array}$ & $\begin{array}{l}\text { Acrostichum } \\
\text { leaf }\end{array}$ & $\begin{array}{l}\text { Acrostichum } \\
\text { stem }\end{array}$ & $\begin{array}{l}\text { Cladium } \\
\text { whole } \\
\text { plant }\end{array}$ & $\begin{array}{l}\text { Pterocarpus } \\
\text { leaf }\end{array}$ & $\begin{array}{l}\text { Pterocarpus } \\
\text { wood }\end{array}$ \\
\hline Total fucose (\%) & 4.43 & 2.90 & 3.72 & 2.84 & 0.96 & 0.49 & 1.58 & 2.00 \\
\hline Total glucose (\%) & 26.35 & 47.74 & 44.65 & 53.94 & 67.96 & 71.56 & 48.69 & 59.47 & 65.45 \\
\hline Total mannose (\%) & 3.95 & 4.63 & 6.94 & 3.92 & 9.65 & 9.55 & 6.65 & 4.82 \\
\hline Total galactose (\%) & 28.14 & 6.23 & 13.23 & 8.11 & 9.22 & 3.03 & 3.05 & 8.54 \\
\hline
\end{tabular}


Table 2. : Lignin phenols depth distribution beneath the various mangrove swamps studied, i.e. Rhizophora mangle, Laguncularia racemosa, Acrostichum aureum, Cladium marescus, and Pterocarpus officinalis: $\mathrm{X}_{\text {lignin }}$ in mmol phenolic $\mathrm{C} / 100 \mathrm{mmol}$ total $\mathrm{OC}$, Vanillic unit, Syringic unit, Cinnamic unit in \% of total phenols, vanillic acid/vanillin ratios $(\mathrm{Ad} / \mathrm{Al})_{\mathrm{v}}$, syringic acid/syringaldehyde $(\mathrm{Ad} / \mathrm{Al})_{\mathrm{s}}$

\begin{tabular}{|c|c|c|c|c|c|c|c|}
\hline $\begin{array}{l}\text { Mangrove } \\
\text { species }\end{array}$ & $\begin{array}{l}\text { Depth } \\
\text { (cm) }\end{array}$ & $\begin{array}{l}X_{\text {lignin }}(\mathrm{mmol} \text { phenolic } \\
\text { C/100 mmol TOC) }\end{array}$ & $\begin{array}{l}V \\
(\%)\end{array}$ & $\begin{array}{l}S \\
(\%)\end{array}$ & $\begin{array}{l}\text { C } \\
(\%)\end{array}$ & $(\mathrm{Ad} / \mathrm{Al})_{\mathrm{v}}$ & $(\mathrm{Ad} / \mathrm{Al})_{\mathrm{s}}$ \\
\hline \multirow[t]{4}{*}{ Rhizophora } & 1 & 7.7 & 50 & 23 & 8 & 0.26 & 0.23 \\
\hline & 13 & 4.5 & 47 & 25 & 15 & 0.42 & 0.35 \\
\hline & 37 & 4.8 & 37 & 25 & 24 & 0.10 & 0.32 \\
\hline & 158 & 4.5 & 53 & 31 & 6 & 0.31 & 0.29 \\
\hline \multirow[t]{4}{*}{ Laguncularia } & 1 & 8.6 & 47 & 37 & 2 & 0.37 & 0.27 \\
\hline & 25 & 4.7 & 53 & 36 & 2 & 0.63 & 0.59 \\
\hline & 65 & 1.8 & 48 & 31 & 8 & 0.90 & 0.58 \\
\hline & 178 & 3.8 & 50 & 34 & 4 & 0.30 & 0.28 \\
\hline \multirow[t]{5}{*}{ Acrostichum } & 1 & 4.0 & 66 & 11 & 5 & 0.42 & 0.37 \\
\hline & 13 & 4.5 & 78 & 11 & 3 & 0.48 & 0.27 \\
\hline & 49 & 4.4 & 56 & 32 & 5 & 0.53 & 0.39 \\
\hline & 102 & 2.3 & 65 & 20 & 5 & 0.55 & 0.44 \\
\hline & 158 & 3.3 & 59 & 20 & 6 & 0.37 & 0.30 \\
\hline \multirow[t]{5}{*}{ Cladium } & 1 & 4.0 & 35 & 30 & 8 & 0.33 & 0.37 \\
\hline & 13 & 3.2 & 39 & 30 & 9 & 0.58 & 0.35 \\
\hline & 41 & 1.8 & 27 & 22 & 20 & 0.54 & 0.43 \\
\hline & 88 & 2.3 & 31 & 26 & 19 & 0.19 & 0.33 \\
\hline & 133 & 10.0 & 59 & 32 & 3 & 0.47 & 0.45 \\
\hline \multirow[t]{5}{*}{ Pterocarpus } & 1 & 3.3 & 46 & 33 & 7 & 0.38 & 0.38 \\
\hline & 13 & 3.5 & 61 & 25 & 3 & 0.53 & 0.42 \\
\hline & 49 & 1.8 & 53 & 29 & 6 & 0.78 & 0.58 \\
\hline & 103 & 5.5 & 58 & 27 & 5 & 1.13 & 1.12 \\
\hline & 143 & 2.9 & 58 & 21 & 10 & 1.20 & 1.00 \\
\hline
\end{tabular}

Table 3. 
Neutral carbohydrates depth distribution beneath the various mangrove swamps studied, i.e. Rhizophora mangle, Laguncularia racemosa, Acrostichum aureum, Cladium marescus, and Pterocarpus officinalis: total carbohydrates in mmol TCHO-C/100 mmol total OC; total ribose, total arabinose, total xylose, total rhamnose, total fucose, total glucose, total mannose, total galactose, hemicellulosic carbohydrates in \% of total carbohydrates 


\begin{tabular}{|c|c|c|c|c|c|c|c|c|c|c|c|}
\hline Mangrove & $\begin{array}{l}\text { Depth } \\
\text { (cm) }\end{array}$ & $\begin{array}{l}\text { Total carbohydrates } \\
\text { (mmol TCHO- } \\
\text { C/100 mmol TOC) }\end{array}$ & $\begin{array}{l}\text { Total } \\
\text { ribose } \\
(\%)\end{array}$ & $\begin{array}{l}\text { Total } \\
\text { arabinose } \\
(\%)\end{array}$ & $\begin{array}{l}\text { Total } \\
\text { xylose } \\
(\%)\end{array}$ & $\begin{array}{l}\text { Total } \\
\text { rhamnose } \\
(\%)\end{array}$ & $\begin{array}{l}\text { Total } \\
\text { fucose } \\
(\%)\end{array}$ & $\begin{array}{l}\text { Total } \\
\text { glucose } \\
(\%)\end{array}$ & $\begin{array}{l}\text { Total } \\
\text { mannose } \\
(\%)\end{array}$ & $\begin{array}{l}\text { Total } \\
\text { galactose } \\
(\%)\end{array}$ & $\begin{array}{l}\text { Hemicellulosic } \\
\text { carbohydrates } \\
(\%)\end{array}$ \\
\hline \multirow[t]{5}{*}{ Rhizophora } & 1 & 7.0 & 2 & 14 & 14 & 10 & 3 & 41 & 10 & 6 & 40 \\
\hline & 13 & 7.0 & 2 & 16 & 15 & 9 & 5 & 36 & 10 & 7 & 27 \\
\hline & 37 & 7.2 & $<1$ & 18 & 15 & 9 & 4 & 35 & 9 & 10 & 45 \\
\hline & 95 & 7.0 & $<1$ & 17 & 14 & 8 & 4 & 40 & 8 & 9 & - \\
\hline & 158 & 3.6 & $<1$ & 26 & 17 & 15 & 5 & 27 & 3 & 6 & 73 \\
\hline \multirow[t]{5}{*}{ Laguncularia } & 1 & 7.5 & $<1$ & 18 & 8 & 5 & 6 & 40 & 10 & 11 & 27 \\
\hline & 25 & 5.4 & 1 & 17 & 7 & 5 & 5 & 45 & 9 & 11 & 36 \\
\hline & 65 & 2.1 & 1 & 17 & 7 & 7 & 3 & 42 & 13 & 9 & 47 \\
\hline & 123 & 2.1 & 2 & 13 & 11 & 9 & 3 & 42 & 10 & 9 & 53 \\
\hline & 178 & 3.9 & 1 & 19 & 10 & 10 & 5 & 36 & 8 & 11 & 58 \\
\hline \multirow[t]{5}{*}{ Acrostichum } & 1 & 7.7 & $<1$ & 10 & 10 & 5 & 3 & 47 & 13 & 11 & 39 \\
\hline & 13 & 5.3 & $<1$ & 11 & 8 & 7 & 4 & 40 & 15 & 15 & 40 \\
\hline & 49 & 3.5 & 1 & 15 & 8 & 6 & 3 & 44 & 13 & 10 & 54 \\
\hline & 102 & 2.1 & 1 & 10 & 7 & 3 & 4 & 57 & 12 & 6 & 27 \\
\hline & 158 & 4.1 & $<1$ & 20 & 9 & 12 & 5 & 36 & 9 & 8 & 56 \\
\hline \multirow[t]{3}{*}{ Cladium } & 1 & 8.8 & 1 & 10 & 12 & 5 & 4 & 40 & 13 & 15 & 63 \\
\hline & 13 & 7.2 & 1 & 10 & 10 & 5 & 4 & 43 & 13 & 14 & 73 \\
\hline & 41 & 6.9 & 1 & 8 & 11 & 4 & 3 & 51 & 11 & 11 & 60 \\
\hline
\end{tabular}




\begin{tabular}{|c|c|c|c|c|c|c|c|c|c|c|c|}
\hline Mangrove & $\begin{array}{l}\text { Depth } \\
\text { (cm) }\end{array}$ & $\begin{array}{l}\text { Total carbohydrates } \\
\text { (mmol TCHO- } \\
\text { C/100 mmol TOC) }\end{array}$ & $\begin{array}{l}\text { Total } \\
\text { ribose } \\
(\%)\end{array}$ & $\begin{array}{l}\text { Total } \\
\text { arabinose } \\
(\%)\end{array}$ & $\begin{array}{l}\text { Total } \\
\text { xylose } \\
(\%)\end{array}$ & $\begin{array}{l}\text { Total } \\
\text { rhamnose } \\
(\%)\end{array}$ & $\begin{array}{l}\text { Total } \\
\text { fucose } \\
(\%)\end{array}$ & $\begin{array}{l}\text { Total } \\
\text { glucose } \\
(\%)\end{array}$ & $\begin{array}{l}\text { Total } \\
\text { mannose } \\
(\%)\end{array}$ & $\begin{array}{l}\text { Total } \\
\text { galactose } \\
(\%)\end{array}$ & $\begin{array}{l}\text { Hemicellulosic } \\
\text { carbohydrates } \\
(\%)\end{array}$ \\
\hline & 88 & 5.6 & 1 & 13 & 17 & 3 & 3 & 44 & 8 & 11 & 58 \\
\hline & 133 & 5.5 & $<1$ & 12 & 15 & 4 & 3 & 45 & 8 & 12 & 60 \\
\hline \multirow[t]{5}{*}{ Pterocarpus } & 1 & 5.5 & $<1$ & 15 & 8 & 5 & 4 & 44 & 9 & 13 & 41 \\
\hline & 13 & 5.2 & $<1$ & 12 & 8 & 6 & 4 & 46 & 10 & 13 & 42 \\
\hline & 49 & 3.3 & 2 & 20 & 6 & 7 & 4 & 37 & 11 & 12 & 65 \\
\hline & 103 & 4.4 & $<1$ & 20 & 7 & 4 & 5 & 44 & 7 & 11 & 40 \\
\hline & 143 & 3.7 & $<1$ & 18 & 6 & 5 & 5 & 50 & 7 & 9 & 51 \\
\hline
\end{tabular}


